\title{
Analisis Manajemen Laba pada Laporan Keuangan Perbankan Syariah
}

\author{
Alfiyatur Rohmaniyah" dan Khanifah Khanifah \\ Jurusan Akuntansi, Fakultas Ekonomi, Universitas Wahid Hasyim \\ "Email: Alfiyaturrohmaniyah1997@gmail.com
}

\begin{abstract}
This study aims to analyze earnings management in Islamic banking financial statements (studies on Indonesian Islamic Commercial Banks 2015-2017).in this study the data used is secondary data and uses the 2015-2017financial report at annualreport. The sampling method in this study was purposive sampling with a total of 13 Indonesian Islamic Commercial Banks. The data analysis method used is the discretionary accrual approach, descriptive statistical analysis, multiple regression analysis. The test results that have been carried out during the observation period are in the indexed Islamic Commercial Banks to practice earnings management in the financial statements. This is evidenced by the results of the discretionary accrual (DA) for three years which are negative and positive, discretionary accrual (DA) which has been analyzed has an average below zero,in other words the average DA value is negative, this means Indonesian Islamic Commercial Banks In 2015-2017, earnings magement was carried out by reducing the profit rate.
\end{abstract}

Keywords: earnings management and discretionary accrual.

\begin{abstract}
Abstrak
Penelitian ini bertujuan untuk mengalisis manajemen laba pada laporan keuangan perbankan syariah (studi pada Bank Umum Syariah IndonesiaTahun 2015-2017). Dalam penelitian ini data yang digunakan adalah data sekunder dan menggunakan laporan keuangan periode 2015-2017 di annualreport. Metode pengambilan sampel dalam penelitian ini adalah purposive sampling. Dengan jumlah sebanyak 13 Bank Umum Syariah Indonesia. Metode analisis data yang digunakan adalah pendekatan discretionary accrual, analisis deskriptif statistik, analisis regresi berganda. Hasil pengujian yang telah dilakukan selama periode pengamatan yaitu pada Bank Umum Syariah terindekasi melakukan praktik manajemen laba dalam laporan keuangan. Hal ini dibuktikan dengan hasil Discretionary Accrual (DA) selama tiga tahun yang bernilai negatif dan positif, Discretionary Accrual (DA) yang telah dianalisis memmiliki rata-rata di bawah angka nol, dengan kata lain nilai DA rata-rata bernilai negatif, hal ini berarti Bank Umum Syariah Indonesia Pada tahun 2015-2017 melakukan manajemen laba dengan cara menurunkan angka laba.
\end{abstract}

Kata Kunci: manajemen laba dan discretionary accrual.

\section{PENDAHULUAN}

Setiap tahunnya perusahaan pasti menerbitkan laporan keuangan. Laporan keuangan berfungsi untuk memberikan informasi mengenai posisi keuangan, kinerja perusahaan dan arus kas. Laporan keuangan juga berfungsi sebagai bentuk pertanggungjawaban manajer atas sumber daya yang dikelolanya. Salah satu informasi penting dalam laporan keuangan adalah informasi mengenai laba.

Angka laba menjadi sorotan utama bagi pengguna laporan keuangan yang kemudian dikaitkan dengan prestasi manajemen dan menjadi indikator dalam pengukuran kinerja manajemen. jika pada saat kondisi tertentu manajemen tidak berhasil mencapai target laba yang ditentukan, maka manajemen dapat memanfaatkan fleksibilitas yang diperbolehkan oleh standar akuntansi dalam menyusun laporan keuangan untuk modifikasi laba yang dilaporkan.

Salah satu cara untuk mencapai target laba yang diinginkan adalah dengan melakukan manajemen laba (earnings managemen). Manajemen laba didefinisikan sebagai upaya manajer perusahaan untuk mempengaruhi informasi-informasi dalam laporan keuangan dengan suatu tujuan untuk mengelabuhi stakeholder yang ingin mengetahui kinerja dan kondisi perusahaan. Manajemen laba yang dilakukan oleh manajer tersebut timbul karena keinginan manajer untuk meningkatkan kinerja perusahaan dengan laba besar serta adanya masalah keagenan yaitu konflik kepentingan 
antara pemilik/pemegang saham (principal) dengan pengelola/ manajemen (agent) akibat tidak bertemunya utilitas maksimal diantara mereka.

Dalam pratiknya manajemen melakukan manipulasi laba melalui aktivitas akrual Manipulasi laba melalui aktivitas akrual ini dilakukan karena adanya kebijakan yang telah diatur dalam PSAK No.1 (revisi 2009) paragraph 25, dimana penyusunan laporan keuangan atas dasar akrual kecuali pada laporan arus kas. Secara teknis manajemen laba akrual dilakukan dengan mempermainkan komponen-komponen akrual dalam laporan keuangan. Terdapat berbagai macam model untuk mengukur manajemen laba akrual diantaranya model Healy, model De Angelo, Model Jones dan Model Jones yang dimodifikasi. Dalam penelitian ini, manajemen laba akrual diukur menggunakan modified jones model. Alasan penggunaan model ini karena modified jones model dapat mendeteksi manajemen laba lebih baik dibandingkan dengan model-model lainnya yang sejalan dengan hasil penelitian Dechow et al. (1995).

Manajemen laba merupakan tindakan manajer untuk meningkatkan (mengurangi) laba yang dilaporkan saat ini atas suatu unit dimana manajer bertanggung jawab, tanpa mengakibatkan peningkatan (penurunan) profitabilitas ekonomis jangka panjang unit tersebut. Healy dan Wahlen (1999), mendefinisikan manajemen laba terjadi ketika manajer menggunakan judgement dalam laporan keuangan dan penyusunan transaksi untuk mengubah laporan keuangan, sehingga menyesatkan stakeholders tentang kinerja ekonomi perusahaan atau untuk mempengaruhi hasil yang berhubungan dengan kontrak yang tergantung pada angka akuntansi.

Menurut Sulistyanto (2008) dalam Iranto (2014), manajemen laba akrual dilakukan dengan mempermainkan komponen-komponen akrual dalam laporan keuangan, sebab pada komponen akrual dapat dilakukan permainan angka melalui metode akuntansi yang digunakan sesuai dengan keinginan orang yang melakukan pencatatan dan penyusunan laporan keuangan. Komponen akrual merupakan komponen yang tidak memerlukan bukti kas secara fisik sehingga mempermainkan besar kecilnya komponen akrual tidak harus disertai kas yang diterima atau dikeluarkan perusahaan. Misalnya saja biaya depresiasi, untuk mengetahui besarnya biaya ini kita harus mengetahui biaya, umur manfaat, dan metode depresiasi yang digunakan. Nilai biaya memang sudah tetap dan tidak bisa diubah-ubah, namun umur manfaat dan metode depresiasi bisa diubah sesuai dengan kebijakan manajemen.

Menurut Healy dan DeAngelo dalam Imelda dan Suhendah (2011), konsep akrual dibedakan menjadi dua yaitu discretionary accruals dan non discretionary accruals. Discretionary Accruals adalah pengakuan akrual laba atau beban yang bebas serta serta tidak diatur dan merupakan pilihan kebijakan manajemen. sedangkan Non Discretionary Accruals merupakan akrual yang wajar dan tunduk pada prinsip akuntansi yang berterima umum, bila dilanggar dapat mempengaruhi kualitas laporan keuangan menjadi tidak wajar contohnya seperti mesin yang sama dapat didepresiasi dengan dua metode yang berbeda atau umur ekonomis yang berbeda.

Adanya perbankan dapat membantu masyarakat yang membutuhkan dana dari pihak yang memiliki kelebihan dana sehingga dapat membantu masyarakat memperlancar perekonomian masyarakat. Di Indonesia terdapat dua jenis bank yaitu bank konvensional dan bank syariah. Tetapi dapat perbedaan, yaitu bank konvensional menggunakan riba atau bunga sedangkan bank syariah berdasarkan prinsip islam dalam menjalankan suatu kegiatan usahanya. Hal inilah yang menyebabkan berdirinya bank syariah di Indonesia. Berdasarkan rumusan masalah diatas, tujuan dari penelitian ini adalah menganalisis manajemen laba pada laporan keuangan Bank Umum Syariah Indonesia Tahun 2015-2017.

\section{KAJIAN PUSTAKA}

Dalam teori keagenan Agency Theory dijelaskan menurut Anthony dan Govindarajan (1995), Padmantyo (2010), kata "agent" berarti mekanisme yang dihasilkan perusahaan produksi atau perusahaan bisnis yang diatur. Pada dasarnya fungsi agen terkait dengan hubungan antara aturan yang dilakukan. Anthony dan Govindarajan (1995), Padmantyo (2010) mengemukakan asumsi Agency Theory bahwa masing-masing individu semata-mata termotivasi oleh kepentingan dirinya sendiri sehingga menimbulkan konflik kepentingan antara principal dan agent. Principal termotivasi mengadakan kontrak untuk mensejahterakan dirinya sendiri dengan profitabilitas yang selalu meningkat, sedangkan agent termotivasi untuk memaksimalkan pemenuhan kebutuhan ekonomis dan psikologinya. Perbedaaan kepentingan antara agent dan 
principal inilah yang dapat disebut dengan masalah keagenan yang salah satunya disebabkan oleh asimetri informasi. Asimetri informasi merupakan suatu kondisi dimana ada ketidakseimbangan perolehan informasi antara pihak manajemen sebagai penyedia informasi dengan pihak pemegang saham dan stakeholder pada umumnya sebagai pengguna informasi.

\section{METODE PENELITIAN}

Jenis Penelitian ini termasuk penelitian deskriptif kuantitatif. Deskriptif kuantitatif adalah penelitian yang dilakukan untuk mengetahui nilai variabel mandiri, baik satu variabel atau lebih (independen) tanpa memuat perbandingan, atau menghubungkan dengan variabel yang lain dengan memperoleh angka data yang berbentuk angka. Manajemen laba akrual diukur menggunakan modified jones model dengan proksi sisa regresi total akrual dari perubahan penjualan dan asset tetap, artinya pendapatan disesuaikan dengan perubahan piutang yang terjadi pada periode bersangkutan (Uswati et al. 2012).

Manajemen Laba di ukur dengan modified jones model merupakan model pengukuran manajemen laba akrual yang dikembangkan oleh Dechaw et at. (1995). Modified jones model merupakan modifikasi dari model jones yang didesain untuk mengeliminasi kecenderungan untuk menggunakan perkiraan yang salah dari model jones untuk menentukan discretionary accruals ketika discretion melebihi pendapatan.

Laporan keuangan perbankan syariah dianalisis menggunakan Modified Jones Model dengan perhitungan Total Akrual (TAC), Discretonary Accrual (DA), Non Discretionary Accrual (NDA). Sehingga akan menunjukkan ada tidaknya manajemen laba.

Variabel yang digunakan dalam penelitian ini akan dideskripsikan sebagai hasil penelitian. Adapun variabel dalam penelitian ini adalah manajeman laba akrual. Deteksi atas kemungkinan dilakukannya manajemen laba akrual diukur dengan menggunakan proksi discretionary accrual sesuai dengan modified jones model.

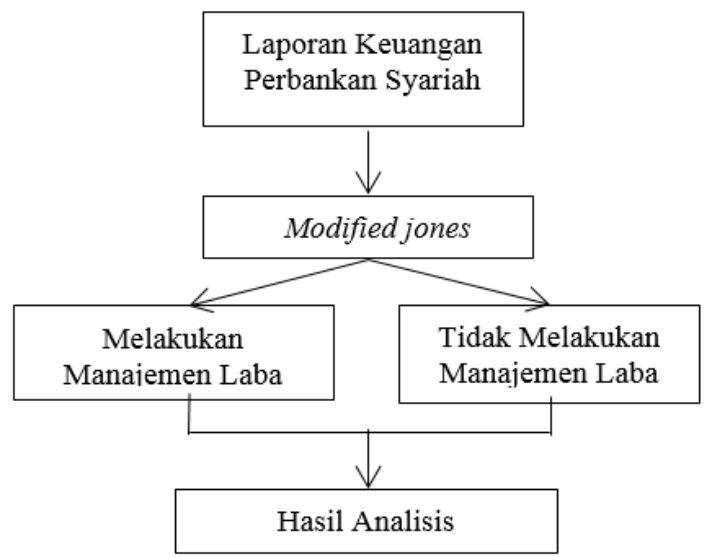

Gambar 1. Kerangka pemikiran

1) Pengukuran Manajemen Laba Akrual dengan modified jones model

a) Discretionary accruals diperoleh dengan mengukur total akrual terlebih dahulu. Dengan rumus:

$$
\begin{aligned}
\mathrm{TAC}_{\mathrm{t}} & =\mathrm{NI}_{\mathrm{t}}-\mathrm{CFO}_{\mathrm{t}} \\
& \text { Keterangan: } \\
& \text { TAC } \quad: \text { Total akrual } \\
\mathrm{NI} & : \text { Laba Bersih } \\
\text { CFO } & : \text { Arus Kas Operasi }
\end{aligned}
$$

b) Selanjutnya dilakukan dekomposisi komponen total accrual kedalam komponen discretionary accrual dengan nondiscretionary accrual. Dekomposisi ini dilakukan dengan mengacu pada modified jones model (Dechow et al. 1995) berikut ini :

$$
\frac{T A C_{t}}{T A i_{t-1}}=a_{1}\left(\frac{1}{T A i_{t-1}}\right)+a_{2}\left(\frac{\Delta R E V_{t}}{T A_{t-1}}\right)+a_{3}\left(\frac{P P E_{t}}{T A_{t-1}}\right) \text { eit }
$$


Keterangan:

TAit-1 : Total asset pada tahun sebelum penelitian

$\triangle \mathrm{REV}_{\mathrm{it}}$ : selisih pendapatan tahun penelitian dengan tahun sebelumnya

$\mathrm{PPE}_{\mathrm{it}} \quad$ : plant, property and equipment

$\alpha$ : koefisien

c) Kemudian mencari nilai nondiscretionary accrual (NDAC) dihitung dengan rumus sebagai berikut

$$
N D A=a_{1}\left(\frac{1}{T A_{t-1}}\right)+a_{2}\left(\Delta R E V_{t}-\frac{\Delta R E C_{t}}{T A_{t-1}}\right)+a_{3}\left(\frac{P P E_{t}}{T A_{t-1}}\right)
$$

Keterangan:

NDAC : nondiscretionary accruals

$\triangle$ REC : selisih piutang tahun penelitian dengan tahun sebelumnya

Koefisien masing-masing variabel dari persamaan diatas didapat dari hasil regresi

d) Untuk menghitung nilai discretionary accrual (DAC) yang merupakan ukuran manajemen laba, diperoleh rumus sebagai berikut:

$$
D A_{t}=\frac{T A C_{t}}{T A_{t-1}}-N D A
$$

Keterangan :

DAC : Discretionary Acruals

Dalam penelitian ini, populasinya adalah Bank Umum Syariah (BUS) yang terdaftar di Bank Indonesia periode tahun 2015-2017 sebanyak 13 bank. Teknik pengambilan sampel dalam penelitian ini adalah purposive sampling dengan kriteria sebagai berikut:

1. Bank Umum Syariah yang mengeluarkan laporan keuangan 3 tahun berturut-turut, yaitu tahun 2015-2017.

2. Periode laporan keuangan berakhir 31 Desember pada tiap tahunnya.

3. Bank Umum Syariah yang mempunyai data lengkap selama kurun waktu 2015-2017.

Metode analisis yang digunakan dalam penelitian ini adalah metode analisis deskriptif kuantitatif yang memberikan gambaran atau deskripsi suatu data yang dilihat dari nilai rata-rata (mean), standar deviasi, varian, maksimum, dan minimum. Standar deviasi, varian, maksimum, dan minimum menunjukkan hasil analisis terhadap dispersi data.

\section{HASIL DAN PEMBAHASAN}

Deskripsi hasil penelitian ini mengambil dari data-data laporan keuangan Bank Umun Syariah Indonesia yaitu berupa laporan posisi keuangan, laporan laba rugi komprehensif dan laporan arus kas. Analisis deskriptif ini menjelaskan masing-masing variabel yang terkait dalam penelitian ini. Penelitian ini menggunakan pendekatan discretionary Accruals untuk mengukur ada atau tidaknya praktik manajemen laba melalui aktivitas akrual dalam laporan keuangan. Penelitian ini menggunakan rumus modified jones model untuk mencari discretionary accruals.

Berdasarkan Tabel 4.1, dapat diketahui bahwa jumlah sampel yang digunakan dalam penelitian ini sebanyak 39 yang terbagi ke dalam 13 Bank Umum Syariah selama periode 20152017. Selama tahun 2015-2017, nilai minimum dari Discretionary Accruals (DA) adalah -0,25838. Sedangkan nilai maksimumnya adalah 0,15408 . Dapat dilihat pula nilai rata-rata Discretionary Accruals yang terjadi dalam periode 2015-2017 sebesar -0,20811026 dan standar deviasinya sebesar 0,07702523 .

Secara keseluruhan Bank Umum Syariah terindikasi melakukan praktik manajemen laba dengan motif yang berbeda-beda tergantung kepentingan tertentu. Nilai Discretionary Accruals tertinggi terjadi pada PT Bank Aceh Syariah pada tahun 2017 sebesar 0,15408. Artinya bahwa PT Bank Aceh Syariah pada tahun 2017 melakukan manajemen laba dengan cara menaikkan angka laba (income maximization) yang paling besar bila dibandingkan dengan Bank Umum Syariah lainnya. Sedangkan nilai Discretionary Accruals terendah terjadi pada PT Bank Aceh Syariah pada tahun 2015 sebesar -0,25838. Artinya bahwa PT Bank Aceh Syariah melakukan manajemen laba dengan cara menurunkan angka laba (income maximization) yang paling tinggi. Sedangkan nilai Discretionary Accruals yang paling baik adalah Discretionary Accruals yang mendekati angka 0 
(nol) terjadi pada PT Maybank Syariah Indonesia pada tahun 2015 sebesar 0,01976. Hal ini menandakan bahwa tidak ada upaya yang besar untuk menaikkan angka laba.

Nilai Mean dari Discretionary Accruals (DA) adalah -0,20811026 hal ini menunjukkan bahwa rata-rata Bank Umum Syariah terindikasi melakukan manajeman laba dengan cara menaikkan laba. Hal ini dapat terjadi akibat beberapa motivasi dari manajeman, misalnya motivasi bonus, motivasi utang, motivasi penjualan saham, dan motivasi pergantian direksi (Watts dan Zimmerman, 1986). Akibat motivasi-motivasi tersebut, manajer melakukan praktik manajemen laba agar supaya dapat memaksimalkan keuntungan yang ia dapatkan.

Analisis deskriptif ini menjelaskan masing-masing variabel yang terkait dalam penelitian ini. Penelitian ini menggunakan discretionary accruals untuk mengukur ada atau tidaknya praktik manajemen laba melalui aktivitas akrual dalam laporan keuangan. Penelitian ini menggunakan rumus modified jones model untuk mencari discretionary accrual.

Dari tabel Discretionary Accruals dengan Model Jones (1991) menunjukkan bahwa pada tahun 2015-2017 menunjukkan bahwa Bank Umum Syariah melakukan manajemen laba. Pada tahun 2015-2017 Bank Umum Syariah melakukan manajemen laba yang bernilai positif atau negatif hal ini berarti adanya manajemen laba pada laporan keuangan Bank Umum Syariah. Nilai Discretionary Accruals yang positif berarti menunjukkan bahwa Bank Umum Syariah melakukan manajemen laba dengan cara menaikkan angka laba yang dilaporkan. Sedangkan Discretionary Accruals yang negatif menunjukkan bahwa Bank Umum Syariah melakukan manajemen laba dengan cara menurunkan angka laba. Berdasarkan Bank Umum Syariah Pada Tahun 2015-2017 yang menujukkan nilai positif dan negatif yaitu sebagai berikut:

Tabel 1. Menunjukkan Bank Umum Syariah Yang Bernilai Positif

\begin{tabular}{|c|c|c|}
\hline $\mathbf{2 0 1 5}$ & $\mathbf{2 0 1 6}$ & $\mathbf{2 0 1 7}$ \\
\hline $\begin{array}{c}\text { PT Bank Muamalat Indonesia } \\
(\text { BMI) }\end{array}$ & $\begin{array}{c}\text { PT Bank Muamalat Indonesia } \\
(\text { BMI })\end{array}$ & PT Bank BCA Syariah \\
\hline PT Bank BCA Syariah & PT Bank Mega Syariah & PT Bank Syariah Bukopin \\
\hline $\begin{array}{c}\text { PT Bank Jabar dan Banten } \\
\text { Syariah }\end{array}$ & PT Bank Panin Dubai Syariah & PT Bank Victoria Syariah \\
\hline PT Bank Syariah Bukopin & PT Bank Syariah Bukopin & PT Bank Aceh Syariah \\
\hline PT Bank Victoria Syariah & PT Bank Victoria Syariah & $\begin{array}{c}\text { PT Bank Tabungan Pensiunan } \\
\text { Nasional Syariah }\end{array}$ \\
\hline PT Maybank Syariah Indonesia & PT Bank Aceh Syariah & - \\
\hline- & - & - \\
\hline
\end{tabular}

Bank Umum Syariah Pada Tahun 2015-2017 menunjukkan nilai Discretionary Accruals bernilai positif. Hal ini berarti Bank Umum Syariah tersebut melakukan manajemen laba dengan cara menaikkan angka laba.

Tabel 2. Menunjukkan Bank Umum Syariah Yang Bernilai Negatif

\begin{tabular}{|c|c|c|}
\hline $\mathbf{2 0 1 5}$ & $\mathbf{2 0 1 6}$ & $\mathbf{2 0 1 7}$ \\
\hline PT Bank BNI Syariah & PT Bank BNI Syariah & PT Bank BNI Syariah \\
\hline PT Bank Mega Syariah & PT Bank Syariah Mandiri & $\begin{array}{c}\text { PT Bank Muamalat Indonesia } \\
\text { (BMI) }\end{array}$ \\
\hline PT Bank Syariah Mandiri & PT Bank BCA Syriah & PT Bank Mega Syariah \\
\hline PT Bank BRI Syariah & PT Bank Jabar dan Banten Syriah & PT Bank Syariah Mandiri \\
\hline PT Bank Panin Dubai Syariah & PT Bank BRI Syariah & PT Bank Jabar dan Banten \\
\hline PT BankAceh Syariah & PT Maybank Syariah Indonesia & PT Bank BRI Syariah \\
\hline $\begin{array}{c}\text { PT Bank Tabungan Pensiunan } \\
\text { Nasional Syariah }\end{array}$ & $\begin{array}{c}\text { PT Bank Tabungan Pensiunan } \\
\text { Nasional Syariah }\end{array}$ & PT Bank Panin Dubai Syariah \\
\hline- & - & PT Maybank Syariah Indonesia \\
\hline
\end{tabular}


Bank Umum Syariah Pada Tahun 2015-2017 menunjukkan nilai Discretionary Accruals bernilai negatif. Hal ini berarti Bank Umum Syariah tersebut melakukan manajemen laba dengan cara menurunkan angka laba.

\section{KESIMPULAN}

Berdasarkan hasil penelitian yang telah dilakukan selama periode pengamatan pada tahun 2015-2017, maka hasil penelitian dapat disimpulkan yaitu pada Bank Umum Syariah terindekasi telah melakukan praktik manajemen laba dalam laporan keuangan periode 2015-2017. Hal ini dibuktikan dengan hasil Discretionary Accrual (DA) selama tiga tahun yang bernilai negatif dan positif, Discretionary Accrual (DA) yang telah dianalisis memiliki rata-rata di bawah angka nol (0), dengan kata lain nilai Discretionary Accrual (DA) rata-rata bernilai negatif, hal ini berarti Bank Umum Syariah Indonesia Pada tahun 2015-2017 melakukan manajemen laba dengan cara menurunkan angka laba.

Berdasarkan kesimpulan yang dikemukakan di atas maka disarankan penelitian selanjutnya diharapkan mengembangkan variabel penelitian seperti kepemilikan manajerial, ukuran perusahaan, kualitas audit, perubahan aturan penyususnan keuangan dan variabel lainnya yang memungkinkan untuk mendeteksi aktifikas accrual dan diharapkan menggunakan semua jenis perusahaan dengan periode pengamatan yang lebih panjang.

\section{DAFTAR PUSTAKA}

Astri Arfani NK dan Noer Sasongko, 2005. Analisis Perbedaan Pengaturan Laba (earnings management) Pada Kondisi Laba dan Rugi Pada Perusahaan Manufaktur di Indonesia, Jurnal Akuntansi dan Keuangan, Vol. 4, No. 1, April 2005, Hal 1-20.

Baharudin I, Satyanugraha, 2008. "Praktik Earnings Management Perusahaan Publik Indonesia". Jurnal Bisnis Dan Akuntansi, Volume 10 No.2, Agustus 2008, Hlm 69-80.

Basuseno, Karno. 2010. Ownership Structure Dan Earning Management Pada Emerging Market: Kasus Indonesia. Universitas Diponegoro Semarang.

Eisenhardt, Kathleem. M. 1989. Agency Theory: An Assesment and Review. Academy of management review, 14, halaman 57-74.

Faradila, Astri dan Ari Dewi Cahyati, “Analisis Manajemen Laba Pada Perbankan Syariah". JRAK Volume 4. No.1, Februari 2013 halaman 57-74.

Fatmawati, Dewi dkk. 2013. Pengaruh Diversifikasi Geografis, Diversifikasi industri, Konsentrasi Kepemilikan Perusahaan, Dan Masa Perikatan Audit Terhadap Manajemen Laba. Universitas Diponegoro Semarang.

Ghozali, Imam, 2011, “Aplikasi Analisis Multivariate Dengan Program IBM SPSS 19”. Badan Penerbitan Universitas Diponegoro Semarang.

Graham, J. R., Harvey, C. R., \& Rajgopal, S. 2005. The Economics Implications of Corporate Financial Reporting. Journal of Accounting and Economics, Vol 40. hal 1-73.

Healy, Paul M. dan James M. Wahlen. 1999. " A Review ot The Earnings Management Literature And Its Implications For Standard Setting”. Accounting Horizonz, Vol. 13. Hal:365-383.

Jones, J.J. 1991. Earnings Management During Important Relief Investigatios. Journal of Accounting Research, 29, (2), 193-228.

Khanifah. 2007.”Pengaruh Masa Penugasan Kantor Akuntan Public, Kepemilikan Manajemen, Dan Keberadaan Komite Audit Terhadap Kualitas Laba (Studi Kasus Pada Perusahaan Non Keuangan Yang Terdaftar Di BEJ)". Universitas Diponegoro Semarang. Tesis

Leuz, C., Nanda, D., \& Wysocky, P. D. 2003. "Earnings Management And Investor Protection: An International Comparison". journal of financial Economics.

Nur'aini, Mufida. 2012."Studi Perbandingan Model Revenue Dan Model Accrual Dalam Mendeteksi Manajemen Laba (studi pada perusahaan manufaktur yang terdaftar di bursa efek Indonesia tahun 2006-2010)". Universitas Diponegor Semarang. Skripsi.

Padmantyo, Sri. 2010. "Analisis Manajemen Laba Pada Laporan Keuangan Perbankan Syariah studi pada Bank Syariah Mandiri dan Bank Muamalat Indonesia". Jurnal manajement dan bisnis. Volume 14, Nomor 2, halaman 53-65.

Roychowdhury, Sugata. 2006. "Earnings Management Through Real Activities Manipulation". Journal of accounting and economics. 
Raharja, Vanian Yamaitya. 2014. "pengaruh asimetri informasi, leverage, dan ukuran perusahaan terhadap praktik manajemen laba (studi empiris pada perusahaan manufaktur yang terdaftar di BEI tahun 2010-2013)". Diponegoro Journal of Accounting. Volume 3 Nomor 4, tahun 2014, halaman 1. ISSN (online):2337-3806.

Sloan. 1995. "Annual Bonus Schemes and Manipulation of Earnings: Additional Evidence on Bonus Plans and Income Management". Journal of Acconting and Economics, 29-74.

Syahfandi, Rizky. 2012. Faktor-Faktor Yang Mempengaruhi Perataan Laba Penyisihan Penghapusan Aktiva Produktif: Praktik Manajemen Laba Pada Perbankan Syariah di Indonesia. Universitas Diponegoro Semarang.

Sugiyono. 2003. Statistik Untuk Penelitian. CV Alfabeta. Bandung.

Sulistyanto, Sri. 2014. Manajemen Laba: Teori Dan Model Empiris. PT Gramedia Widiasarana Indonesia. Jakarta.

Supranto, Johanes. 2001. Statistik Teori Dan Aplikasi. Edisi keenam. Erlangga. Jakarta.

Suranggane, Zulaikha. 2007. "Analisis Aktiva Pajak Tangguhan Dan Akrual Sebagai Predictor Manajemen Laba: Kajian Empiris Pada Perusahaan Manufaktur Yang Terdaftar Di BEJ". Jurna Akuntansi dan Keuangan Indonesia. Volume 4, No. 1 halaman 77-94.

Scoot, William R, 2000, Financial Accounting Theory Second Edition. Canada Prentice Hall.

Uswati, Luluk Dan Sekar Mayangsari, 2012. "Pengaruh Manajemen Laba Terhadap Future Stok Return Dengan Asimetri Informasi Sebagai Variable Moderating". Jurnal Ekonomi Dan Keuangan. ISSN 1411-0393.

Windarti, Esti, Noer Sasongko dan Zulfikar. 2017. “Analisis Perbedaan Kualitas Accrual Antara Sebelum Dan Sesudah Pengadopsian International Financial Reporting Standard (IFRS) Pada Perusahaan Manufaktur Di Indonesia (Study Empris Pada Perusahaan Manufaktur Yang Terdapat Di Bursa Efek Indonesia Tahun 2009-2014)". Riset Akuntansi Dan Keuangan Indonesia, 2(1), 2017.

www.Annualreport.co.id (Di unduh Pada Tanggal 12 Oktober 2018). www.ojk.go.id (Di unduh Pada Tanggal 14 November 2018). 